\title{
The automotive market in the time of global economic crisis
}

\begin{abstract}
The paper presents the role that the automotive sector plays in national economies. The origins of the automotive market crisis have been described as well as its impact on the world and European automotive markets. A condition of the Polish automotive industry and related markets has been discussed indicating relatively moderate consequences of the crisis (as opposed to other countries). The influence of the crisis on the change of buyer preferences has been presented, indicting the shift of the demand towards smaller, cheaper and more energy efficient vehicles. New trends have been shown resulting from the crisis forcing the manufacturers to launch hybrid and electric vehicles as well as alternative fuel vehicles. In the conclusions negative and positive consequences of the crisis have been listed and a production forecast has been made for the coming years.
\end{abstract}

Key words: automotive market, global economic crisis, manufactories vehicles

\section{Rynek motoryzacyjny w dobie światowego kryzysu ekonomicznego}

$W$ artykule przedstawiono rolę, jaka w gospodarce państwa odgrywa sektor motoryzacyjny. Opisano genezę kryzysu przemystu samochodowego oraz jego skutki dla rynków motoryzacyjnych Świata i Europy. Przedstawiono sytuację polskiego przemystu i rynku motoryzacyjnego, wskazując na względnie łagodne, w porównaniu do innych państw, następstwa kryzysu w Polsce. Opisano wplyw kryzysu na zmianę preferencji nabywców samochodów, zaznaczając przesunięcie popytu w kierunku mniejszych, tańszych i bardziej oszczędnych pojazdów. Wskazano na nowe tendencje, spowodowane kryzysem, zmuszajace producentów do wprowadzania na rynek większej liczby pojazdów o napędzie hybrydowym i elektrycznym oraz zasilanych paliwami alternatywnymi. Na zakończenie artykułu podsumowano negatywne i pozytywne skutki kryzysu oraz przedstawiono prognoze produkcji pojazdów w nadchodzacych latach.

Słowa kluczowe: przemysł motoryzacyjny, światowy kryzys ekonomiczny, produkcja pojazdów, sprzedaż pojazdów, rynek samochodowy

\section{Introduction}

An efficient transportation system is a basis for a proper functioning of a developed economy. The key importance of transportation results from its connection with all the branches of economy. Hence, the role of this system in the economy is frequently compared to a bloodstream in a living organism. A malfunctioning operation of a bloodstream is disadvantageous to the whole organism. Similarly, a malfunctioning transportation system has a negative impact on the whole economy. Hence the transportation indexes are tightly related to the economic situation. The course of changes in GDP of the European Union shown in Fig. 1 and transportation of goods and passengers in the years 1995-2006 proves this correlation.

In highly developed countries the transportation systems are chiefly based on road transportation. In Poland the road transportation of goods (counted in tons/kilometers) is approximately 3 times higher that the railroad transportation and 5 times higher than the marine transportation. Road transportation is also dominant in the carrying of passengers. A proper functioning of road transportation is a significant source of income for the national budget. In this context we can show that the tax proceeds of the EU related to the automotive sector amounted

\section{Wprowadzenie}

Sprawny system transportowy jest podstawą prawidłowego funkcjonowania każdego rozwiniętego gospodarczo kraju. Kluczowe znaczenie transportu wynika z jego powiązania z wszystkimi gałęziami gospodarki. Z tego względu rola systemu transportowego $\mathrm{w}$ gospodarce często jest porównywana do roli krwiobiegu w żywym organizmie. Nieprawidłowe działanie układu krwionośnego jest nie-

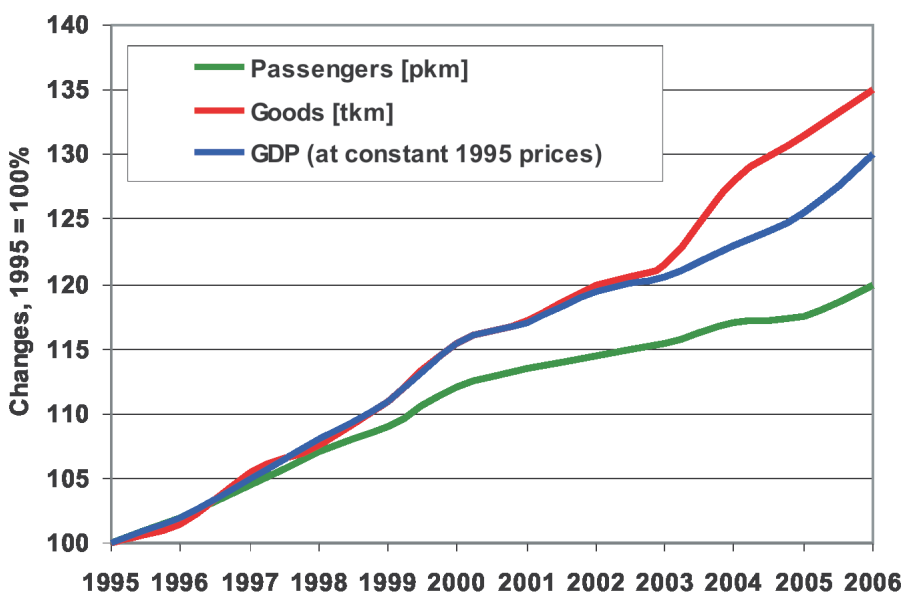

Fig. 1. Changes in EU transport indexes and GDP over the years 1995-2006 [1, 2] Rys. 1. Zmiany wskaźników przewozowych na tle PKB UE w latach 1995-2006 [1, 2] 
to 381 billion euro in 2007 which corresponds to over $3.5 \%$ of EU GDP.

Such economic significance of the road transportation results not only from the transportation tasks. The activity related to the production of the means of transportation plays an important part in the economies of developed countries. We should note that in the EU the employment in the automotive manufacturing sector amounts to approximately 2.2 million people, which constitutes approximately $6,5 \%$ of the total employment in the manufacturing industry (for Poland this index is 5\%). The employment in all the branches of the economy related to the automotive industry amounts to 12.1 million people, which constitutes $6 \%$ of all the people employed in the EU.

The production of vehicles depends on the market demand. This demand depends on the economic situation which, as said earlier, is related to the demand for transportation services. Hence, the sales of commercial vehicles is dependent on the economic situation (Fig. 2). The demand for passenger vehicles is a bit less dependent on the condition of the economy (Fig. 3) as they are only partly used in the economic activities. However, a limited access to financing during the economic crisis and the lack of financial stability results in a lower decreasing trend of the purchasers to buy new passenger vehicles.

Thus, we must state that the condition of the automotive industry is greatly dependent on the general condition of the world economy. This is confirmed by the current crisis in the automotive sector, though initiated by other causes, yet intensified by the financial crisis.

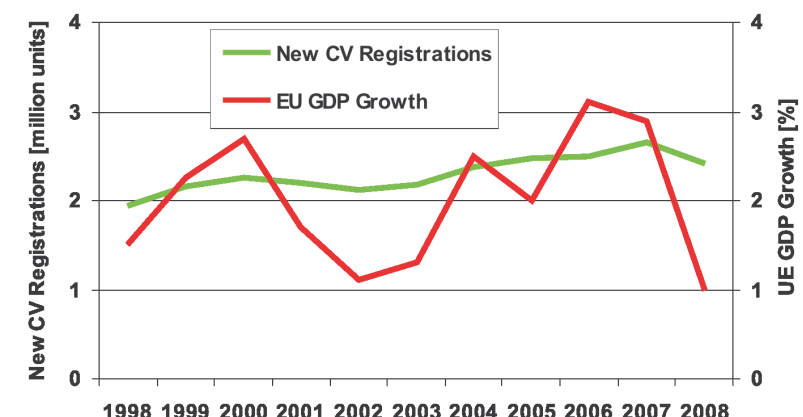

Fig. 2. New commercial vehicle registrations and GDP growth in the EU $[1,2]$

Rys. 2. Rejestracja nowych pojazdów użytkowych $w U E$ a wzrost $P K B[1,2]$

\section{The origin of the crisis and its impact on the world and European automotive market}

The crisis in the automotive industry which is a part of the global economic recession has influenced the manufacturers in the whole world, but the US was the first to experience that in its strongest form. The American automotive industry had already been weakened by the growing fuel prices related to the energy crisis in the years 2003-2008 (Fig. 4). This crisis deterred the Americans from buying SUVs and pick-up trucks characterized by a high fuel korzystne dla funkcjonowania całego organizmu. Podobnie nieprawidłowe funkcjonowanie systemu transportowego wywiera negatywny wpływ na całą gospodarkę, stąd też wskaźniki transportowe są ściśle powiązane z koniunkturą. Przedstawiony na rys. 1 przebieg zmian PKB Unii Europejskiej oraz przewozów towarowych i pasażerskich w latach 1995-2006 potwierdza tę zależność.

W krajach wysoko rozwiniętych system transportowy głównie opiera się na transporcie drogowym. W Polsce przewozy towarów transportem samochodowym (liczone w tonokilometrach) są około trzy razy większe niż przewozy kolejowe i ponad pięć razy większe niż przewozy transportem morskim. Transport samochodowy dominuje również w przewozach pasażerskich. Dobre funkcjonowanie transportu samochodowego stanowi istotne źródło dochodu budżetów państw. W tym kontekście można wskazać, że dochody podatkowe Unii Europejskiej związane z motoryzacją wyniosły w 2007 r. ponad 381 miliardów euro, co odpowiada ponad 3,5\% PKB Unii Europejskiej.

Bardzo istotne znaczenie gospodarcze transportu samochodowego wynika nie tylko z realizacji zadań transportowych. Również działalność związana z produkcją środków transportu odgrywa istotną rolę w gospodarkach krajów rozwiniętych. Warto zauważyć, że w Unii Europejskiej zatrudnienie w produkcji pojazdów wynosi około $2,2 \mathrm{mln}$ osób, co stanowi około 6,5\% zatrudnienia w przemyśle wytwórczym (dla Polski wskaźnik ten wynosi 5\%). Natomiast zatrudnienie we wszystkich gałęziach gospodarki związanych z motoryzacją wynosi 12,1 mln osób, co stanowi $6 \%$ wszystkich zatrudnionych w Unii.

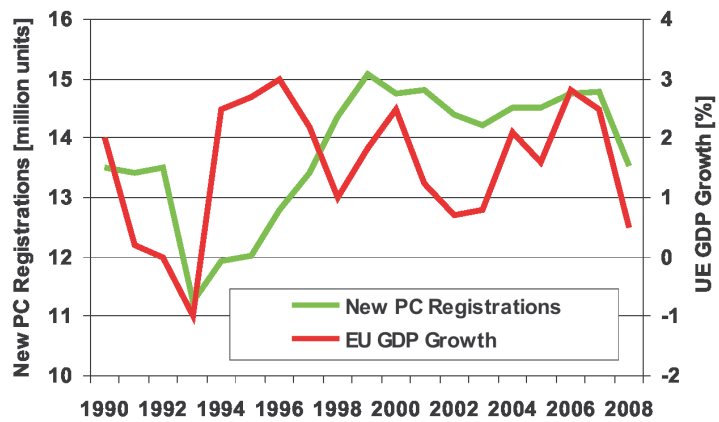

Fig. 3. New passenger car registrations and GDP growth in the EU $[1,2]$ Rys. 3. Rejestracja nowych samochodów osobowych w UE a wzrost PKB

Produkcja pojazdów zależy od zapotrzebowania rynku. Zapotrzebowanie to z kolei zależy od koniunktury gospodarczej, która, jak już wspomniano, jest powiązana z zapotrzebowaniem na przewozy. Stąd też sprzedaż pojazdów użytkowych jest bardzo uzależniona od sytuacji gospodarczej (rys. 2). Popyt na samochody osobowe jest nieco słabiej powiązany ze stanem gospodarki (rys. 3), gdyż są one tylko w części wykorzystywane w działalności gospodarczej. Jednak na przykład utrudniony w okresie recesji dostęp do kredytów oraz niepewność sytuacji wpływają na mniejszą skłonność nabywców do zakupu samochodów osobowych. 
consumption. Vehicles of this type constituted the basic profile of production for the so called big three - General Motors, Ford and Chrysler. As the availability of vehicles characterized by low fuel consumption was miniscule the sales of the big three began to drop. In the top 10 vehicles by Consumer Reports in 2006 not a single American car was listed. The situation was aggravated by the growing labor costs related to a strong position of trade unions. The final stab for the American automotive industry was the coming of the economic crisis that resulted in a limited financing, increase in the prices of raw materials and deteriorating financial situation of the potential buyers. The same consequences impacted the car manufacturers in the whole world though, to a lower extent than it was in the case of America.
Tak więc należy stwierdzić, że kondycja przemysłu motoryzacyjnego jest bardzo uzależniona od ogólnego stanu gospodarki światowej. Potwierdzeniem tego jest obecny kryzys przemysłu motoryzacyjnego, który, jakkolwiek zapoczątkowany innymi przyczynami, został istotnie pogłębiony przez kryzys finansowy.

\section{Geneza kryzysu i jego wpływ na rynek samochodowy świata i Europy}

Kryzys przemysłu motoryzacyjnego, który jest częścią globalnego spowolnienia gospodarczego, dotknął producentów na całym świecie, jednak najwcześniej i najsilniej pojawił się w USA. Amerykański przemysł samochodowy był już osłabiony przez rosnące ceny paliw związane z kryzysem energetycznym w latach 2003-2008 (rys. 4). Kryzys ten zniechęcił klientów do zakupów pojazdów typu SUV i pick-up, które charakteryzowały się dużym zużyciem paliwa. Pojazdy tego typu stanowiły podstawowy profil produkcji tzw. „wielkiej trójki”, czyli firm General Motors, Ford i Chrysler. Wobec niewielkiej oferty pojazdów o mniejszym zużyciu paliwa, sprzedaż produktów „wielkiej trójki” zaczęła spadać. W ogłoszonym przez amerykański magazyn Consumer Reports w 2006 r. rankingu dziesięciu najlepszych samochodów nie znalazł się już ani jeden samochód amerykański. Sytuację pogarszały wysokie koszty pracy, związane z silną pozycją związków zawodowych. Ostatecznym jednak Rys. 4. Ceny ropy naftowej w latach 1997-2009 [3]

The main effect of the crisis is a significant drop in the production and sales of vehicles. It is forecasted that the production of light-duty vehicles in 2009 will be $50 \%$ lower than the year 2000 - the best in the last two decades (Fig. 5). In the EU and Japan the production of LDV will be approximately $25 \%$ lower than in their best years: 2001 for the EU, 2008 for Japan. Only the production in the emerging markets such as Brazil, China, India and Russia will drop insignificantly. The production in these markets has been growing since 2000 and due to the crisis it is merely to remain on a constant level.

In the EU the drop in the sales has most significantly afflicted the sector of commercial vehicles (Fig. 6). The drop in the sales over $20 \%$ came in August 2008. The worst month to date was April 2009 when the sales of the commercial vehicles were more than $40 \%$ lower than last year. In the subsequent months the drop in the sales was high as well and amounted to over 30\%. The drop in the sales of the commercial vehicles was on the average level for the whole EU (Fig. 7) and was the lowest for the new EU member states. Bulgaria, Czech Republic, Estonia, Latvia and Romania have had a drop of approximately $70 \%$. ciosem dla amerykańskiego przemysłu samochodowego było nadejście kryzysu finansowego, którego skutkiem było ograniczenie kredytów, wzrost cen surowców oraz pogorszenie możliwości finansowych potencjalnych nabywców. Te same skutki dotknęły także producentów samochodów na całym świecie, choć w mniejszym stopniu niż koncerny amerykańskie.

Głównym efektem kryzysu jest znaczny spadek produkcji i sprzedaży samochodów. Przewiduje się, że w USA produkcja pojazdów light-duty (LDV) w 2009 r. będzie o prawie połowę mniejsza $\mathrm{w}$ porównaniu do najlepszego $\mathrm{w}$ ostatnich dwu dekadach roku 2000 (rys. 5). W Unii Europejskiej i Japonii produkcja pojazdów LDV będzie o około 25\% mniejsza niż w najlepszych latach: rok 2001 dla Unii Europejskiej, 2008 dla Japonii. Jedynie produkcja na rynkach wschodzących, takich jak Brazylia, Chiny, Indie i Rosja nie będzie istotnie zmniejszona. Produkcja na tych rynkach od 2000 r. systematycznie wzrastała, natomiast teraz ulegnie stagnacji.

W Unii Europejskiej spadek sprzedaży najbardziej dotknął segment pojazdów użytkowych (rys. 6). Przekraczający 20\% spadek sprzedaży nastąpił w sierpniu 2008 r. 

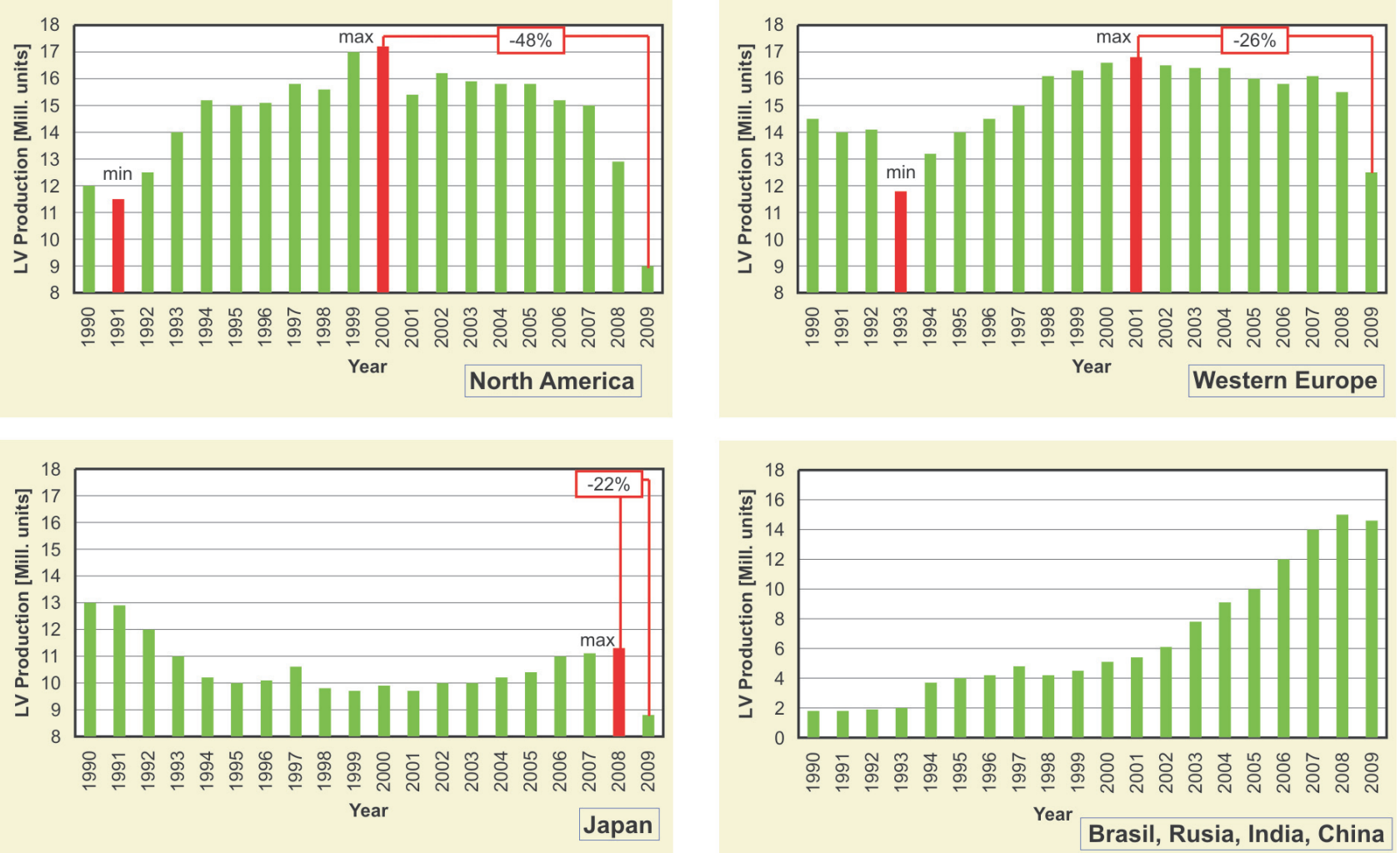

Fig. 5. Production of LDVs in different parts of the world 1990-2009 [4] Rys. 5. Produkcja pojazdów LDV w różnych częściach świata w latach 1990-2009 [4]

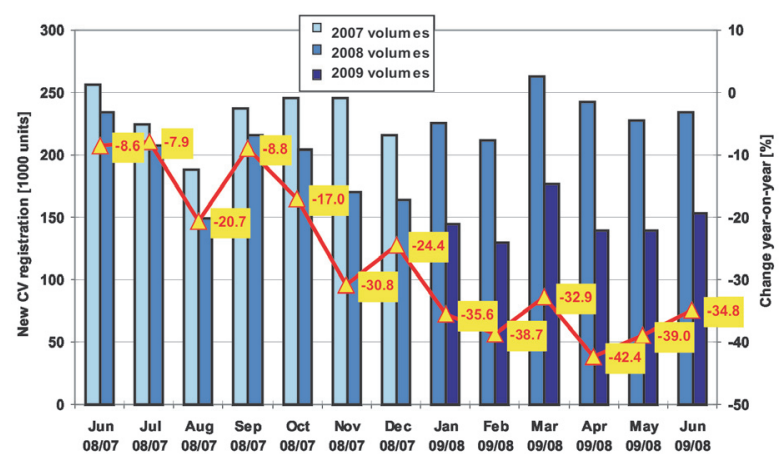

Fig. 6. New commercial vehicle registration in Europe from June 2008 to June 2009 [2]

Rys. 6. Rejestracje nowych samochodów użytkowych $w$ Europie od czerwca 2008 r. do czerwca 2009 r. [2]

The European market of passenger vehicles did not feel such a strong impact of the crisis as it was in the case of earlier described market of commercial vehicles. The first symptoms of the drop in the passenger vehicle sales were seen in August 2008 (Fig. 8) and the worst results in the said sales were recorded at the end of 2008 and the beginning of 2009. Ever since, the situation began to improve. In April 2009 the drop in the sales still exceeded $10 \%$ but in June for the first time in 14 months a slight growth in the sales was recorded. The April data (Fig. 9) indicate that Poland belonged to a unique group of countries where a growth in the number of newly registered passenger vehicles had been recorded.

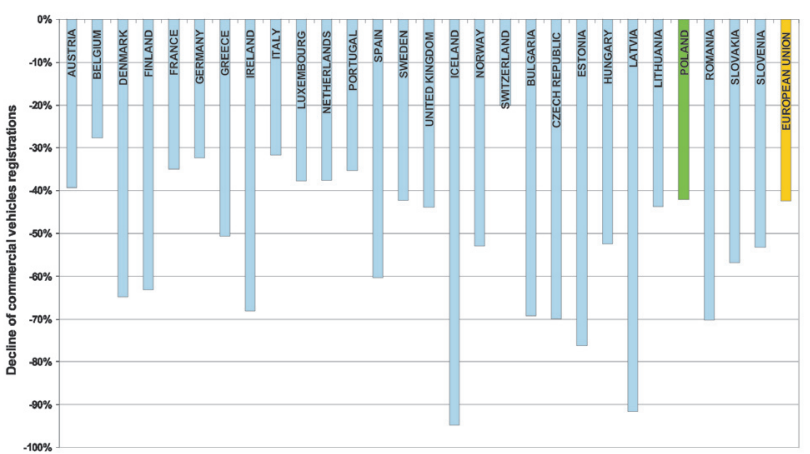

Fig. 7. Decline of new commercial vehicle registrations in Europe (April 2009 to April 2008) [2]

Rys. 7. Spadek liczby rejestrowanych pojazdów użytkowych w poszczególnych krajach europejskich (kwiecień 2009 r. w odniesieniu do kwietnia 2008 r.) [2]

Najgorszym miesiącem dotychczas był kwiecień 2009 r., gdy sprzedaż samochodów użytkowych była o ponad 40\% mniejsza niż rok wcześniej. W kolejnych miesiącach spadek sprzedaży był także duży i wynosił ponad 30\%. Zmniejszenie sprzedaży pojazdów użytkowych w Polsce kształtowało się na poziomie średnim dla całej Unii Europejskiej (rys. 7) i było najmniejsze pośród nowych krajów członkowskich Unii. Bułgaria, Republika Czeska, Estonia, Łotwa i Rumunia odnotowały spadek sprzedaży rzędu 70\%.

Europejski rynek samochodów osobowych w mniejszym stopniu odczuł skutki kryzysu niż omówiony wcześniej rynek samochodów użytkowych. Pierwsze symptomy istotnego 


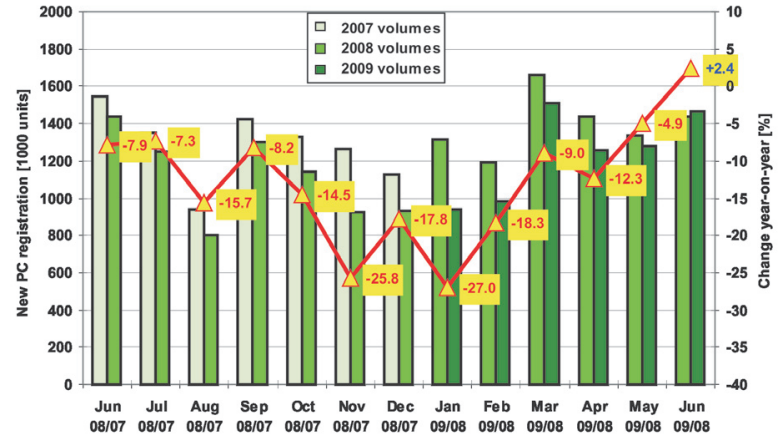

Fig. 8. New passenger car registrations in Europe from June 2008 to June 2009 [2]

Rys. 8. Rejestracje nowych samochodów osobowych w Europie od czerwca 2008 r. do czerwca 2009 r. [2]

The increase in the sales of new passenger vehicles is related to the subsidies from the EU member states and other incentives to recycle old vehicles and buy new ones (Fig. 10). In the largest automotive European market- Germany, the subsidies ended on 2 September 2009 and there were 2 million beneficiaries of this project. This project has also resulted in a several per cent increase in the sales in Polish dealerships. There is, however, a probability that without the sales artificial stimulating subsidies the drop in the sales in Germany may reach as much as $25 \%$, which will make any attempts to correct the automotive market situation difficult. In Poland there were several scenarios of how to encourage drivers to exchange their old cars for new ones. Unfortunately, no projects were introduced that would stimulate the demand for new vehicles. That is why we should give Poland a high credit for the excellent sales results confirming a very stable financial situation of the buyers. spadku sprzedaży samochodów osobowych pojawiły się w sierpniu 2008 r. (rys. 8), a najgorsze wyniki sprzedaży samochodów osobowych zanotowano na przełomie 2008 i 2009 r. Od tego czasu sytuacja ulega poprawie. Jeszcze w kwietniu 2009 r. spadek sprzedaży przekraczał 10\%, natomiast $\mathrm{w}$ czerwcu odnotowano po raz pierwszy od 14 miesięcy niewielki wzrost sprzedaży. Dane z kwietnia wskazują (rys. 9), że Polska należała do nielicznego grona krajów, w których nastąpił wzrost liczby rejestracji nowych samochodów osobowych.

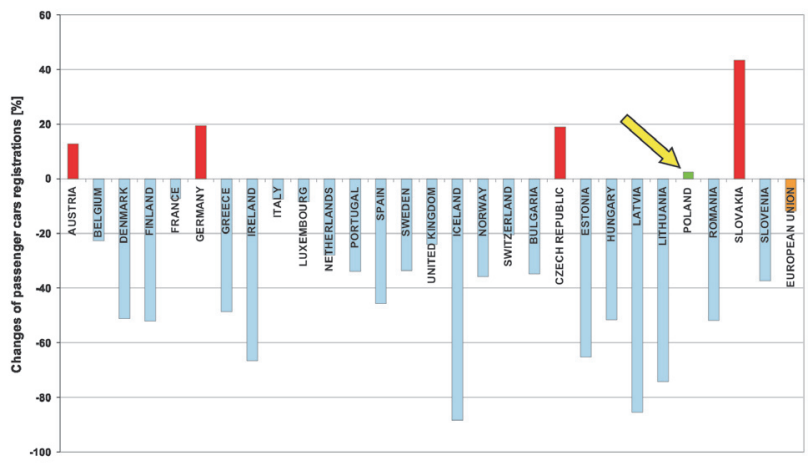

Fig. 9. Changes in new passenger car registrations in Europe (April 2009 to April 2008) [2]

Rys. 9. Zmiana liczby rejestracji nowych samochodów osobowych w poszczególnych krajach europejskich (kwiecień 2009 r. w odniesieniu do kwietnia 2008) [2]

Wzrost sprzedaży samochodów osobowych w dużym stopniu związany jest z wprowadzonymi w wielu krajach Unii Europejskiej programami dopłat i innych zachęt do złomowania starych i zakupu nowych samochodów (rys. 10). Na największym motoryzacyjnym rynku Europy - rynku niemieckim, program dopłat zakończył się 2 września 2009 r. i skorzystało z niego prawie $2 \mathrm{mln}$ klientów. Program ten spowodował również kilkunastoprocentowy wzrost sprzedaży samochodów w polskich salonach. Istnieje, niestety, uzasadniona obawa, że bez dopłat, które stymulowały sztuczny popyt, spadek przyszłorocznej sprzedaży w Niemczech może wynieść nawet $25 \%$, co znacznie utrudni poprawę sytuacji przemysłu motoryzacyjnego. W Polsce rozważane były różne scenariusze zachęt do wymiany samochodów na nowe. Ostatecznie jednak nie wprowadzono żadnego programu stymulującego popyt na nowe samochody. Dlatego bardzo wysoko należy ocenić dobre wyniki sprzedaży samochodów w Polsce, które świadczą o stabilnej sytuacji finansowej klientów.
Fig. 10. Current fleet renewal schemes in the EU countries [2]

Rys. 10. Działania stymulujące odnowę floty samochodów w różnych krajach UE [2] 


\section{The situation of the automotive industry and automotive market in Poland}

The automotive industry in Poland is one of the most important branches of the Polish economy. It has a 9.5\% share in the production of sold items and almost a $16 \%$ share in the whole export from Poland in 2007. The automotive branch is also the largest employer in Poland.

In Europe Poland one of the most important vehicle manufacturer- Approximately $4 \%$ of the European automotive production comes from Poland. The employment in the automotive industry is not much lower than that of the UK, Italy and Spain (Fig. 11) and places our country in the sixth position in the EU. As far as the number of registered passenger vehicles is concerned Poland is also in the sixth position (Fig. 12). The main automotive production in Poland is realized in 16 facilities as shown in table 1.

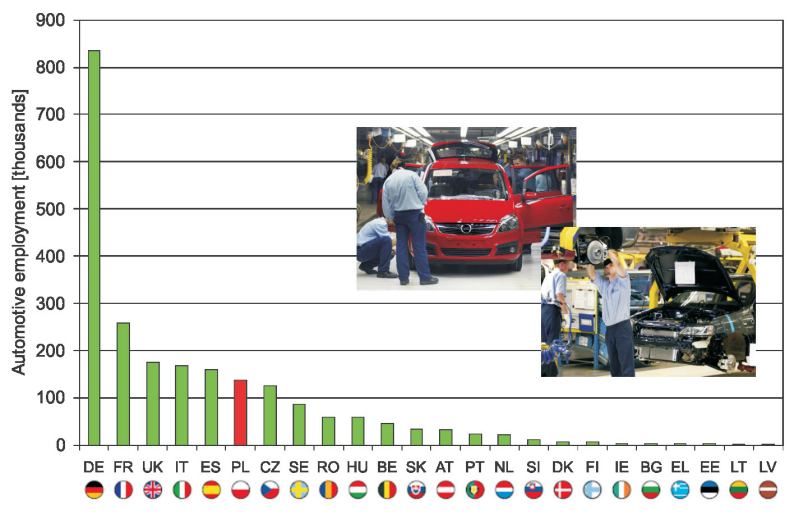

Fig. 11. Direct automotive employment by country (EU) $[2,5]$

Rys. 11. Zatrudnienie w przemyśle motoryzacyjnym w poszczególnych krajach UE [2, 5]

\section{Sytuacja przemysłu i rynku motoryzacyjnego w Polsce}

Przemysł motoryzacyjny w Polsce należy do najważniejszych sektorów polskiej gospodarki, mając 9,5-procentowy udział w produkcji sprzedanej oraz blisko 16-procentowy udział w całym eksporcie z Polski w 2007 r. Branża samochodowa zaliczana jest także do grupy największych pracodawców.

W skali Europy Polska należy do liczących się producentów pojazdów - z Polski pochodzi około 4\% europejskiej produkcji motoryzacyjnej. Zatrudnienie w przemyśle motoryzacyjnym w Polsce jest niewiele mniejsze niż w Wielkiej Brytanii, Włoszech i Hiszpanii (rys. 11) i plasuje nasz kraj na szóstym miejscu w Unii Europejskiej. Również szóste miejsce zajmuje Polska pod względem liczby zarejestrowanych samochodów osobowych (rys. 12). Główna

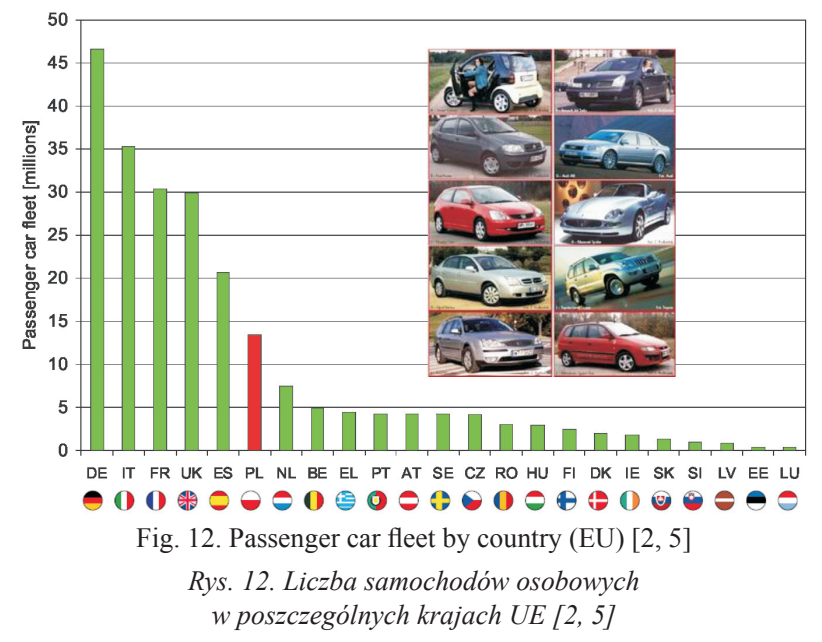

Table 1. Main automotive manufacturing facilities in Poland

Tabela 1. Główne motoryzacyjne zakłady produkcyjne w Polsce

\begin{tabular}{|c|c|c|c|}
\hline No. & Location & Manufacturer & Product \\
\hline 1 & Bielsko-Biała & FIAT-GM & Engines, passenger vehicles/silniki, samochody osobowe \\
\hline 2 & Bolechowo k. Poznania & Solaris & Busses and coaches/autobusy \\
\hline 3 & Gliwice & General Motors Europe & Passenger vehicles/samoch. osobowe \\
\hline 4 & Jelcz-Laskowice & Toyota Motor Europe & Engines/silniki \\
\hline 5 & Lublin & ANDORIA MOT & Engines, light duty trucks/silniki, samochody dostawcze \\
\hline 6 & Niepołomice & MAN Nutzfahrzeuge & Trucks/samochody ciężarowe \\
\hline 7 & Polkowice & Volkswagen AG & Engines/silniki \\
\hline 8 & Poznań & MAN Nutzfahrzeuge & Buses/autobusy \\
\hline 9 & Poznań & Volkswagen AG & Light duty trucks/samoch. dostawcze \\
\hline 10 & Słupsk & Scania AB & Buses/autobusy \\
\hline 11 & Starachowice & MAN Nutzfahrzeuge & Trucks, coaches/samochody ciężarowe, autobusy \\
\hline 12 & Tychy & FIAT Group & Passenger vehicles/samoch. osobowe \\
\hline 13 & Wałbrzych & Toyota Motor Europe & Engines, transmissions/silniki, skrzynie biegów \\
\hline 14 & Warszawa & UKRAVTO & Passenger vehicles/samoch. osobowe \\
\hline 15 & Wrocław & AB VOLVO & Trucks, buses/samochody ciężarowe, autobusy \\
\hline 16 & Wrocław & Jelcz & Buses/autobusy \\
\hline 17 & Wrocław & Toyota Motor Europe & Engines/silniki \\
\hline
\end{tabular}


In 2008 in Poland a record number of passenger vehicles and light duty trucks were manufactured (931 500 units). A year before only 789.000 were manufactured. The production of vehicles in Poland is directly proportional to the demand in the foreign markets; most of the domestic production goes to export sales. The result of the crisis in the European markets was a $21 \%$ drop in the production of vehicles in the first half of 2009 as compared to the perfect 2008. It is, beyond doubt, a significant reduction in the production but it should be noted that other European markets feel the crisis even more. A better situation of Poland is a result of a stronger interest in small and cheap vehicles in the Western Europe the production of which constitutes the majority of our domestic automotive manufacturing. The small and cheap vehicle option is most frequently chosen by those who can benefit from the subsidies for recycling of their old cars in France and Germany. Among the Polish facilities that take the biggest advantage is FIAT which increases production in the time of crisis (Fig. 13).

Despite a growing production in the Tychy FIAT Auto Poland facility the production of the engines in BielskoBiała FIAT-GM Powertrain dropped significantly (Fig. 13). A similar situation is forecasted in the Volkswagen Motor Polska engine manufacturing facility in Polkowice (Fig. 14). The drop in the demand for diesel engines should be credited to a global reduction in the vehicle production and the fact that most of the buyers now choose the cheapest, gasoline models. In the Volkswagen facility in Poznan where light duty trucks are manufactured a production similar to previous years is forecasted. From the presented data we can draw a conclusion that the crisis in Poland is related to facilities manufacturing subassemblies rather that whole vehicles.
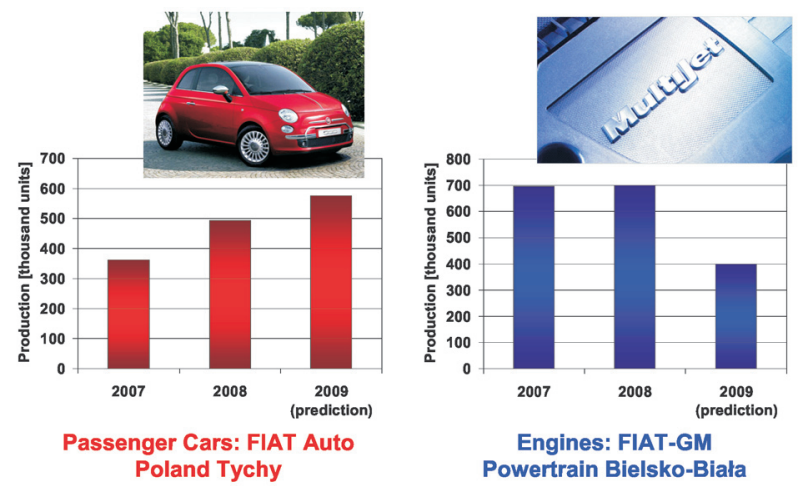

Fig. 13. The influence of the crisis on two FIAT automotive works located in Poland [6]

Rys. 13. Wpływ kryzysu na produkcję w polskich zakładach FIAT-a [6]

The only sector in the European automotive market that did not see a drop in the sales as a result of the crisis is the sector of buses. The orders for these vehicles are placed way in advance and their purchase is mostly financed from public resources. Poland is a large manufacturer of buses in Europe. There are several bus manufacturing plants in Poland that belong to foreign concerns (tab. 1) and a truly domestic manufacturerSOLARIS. The latter forecasts in 2009 a further growth in the sales as compared to a very good 2008 (Fig. 15). produkcja branży motoryzacyjnej w Polsce realizowana jest w szesnastu zakładach, których profil produkcyjny przedstawiono w tab. 1.

W roku 2008 wyprodukowano w Polsce rekordową liczbę, bo około 931,5 tys. samochodów osobowych i dostawczych. Rok wcześniej powstało niespełna 789 tys. pojazdów. Produkcja samochodów w Polsce jest wprost proporcjonalna do popytu na samochody na rynkach zagranicznych; większość rodzimej produkcji jest bowiem sprzedawana poza granicami Polski. Wynikiem kryzysu na rynkach europejskich był 21-procentowy spadek produkcji samochodów w Polsce w pierwszym półroczu 2009 r. w porównaniu z doskonałym rokiem 2008. Jest to niewątpliwie znaczna redukcja produkcji, niemniej należy zauważyć, że inne rynki europejskie odczuwają kryzys w jeszcze większym stopniu. Lepsza sytuacja Polski wynika w dużej mierze ze zwiększonego zainteresowania małymi, tanimi samochodami $\mathrm{w}$ Europie Zachodniej, których produkcja stanowi znaczną część krajowego przemysłu samochodowego. Najczęściej wybierają je kierowcy korzystający z dopłat za złomowanie starego samochodu w Niemczech i Francji. Wśród polskich zakładów motoryzacyjnych najbardziej korzysta z tego firma FIAT, która w czasach kryzysu zwiększa produkcję pojazdów (rys. 13).

Mimo rosnącej produkcji samochodów w zakładach FIAT Auto Poland w Tychach, produkcja silników w fabryce FIAT-GM Powertrain w Bielsku-Białej znacznie się zmniejszyła (rys. 13). Podobna sytuacja przewidywana jest także w wytwórni silników w zakładach Volkswagen Motor Polska w Polkowicach (rys. 14). Spadek zapotrzebowania na silniki o zapłonie samoczynnym należy wiązać z mniejszą globalnie produkcją samochodów oraz tym, że

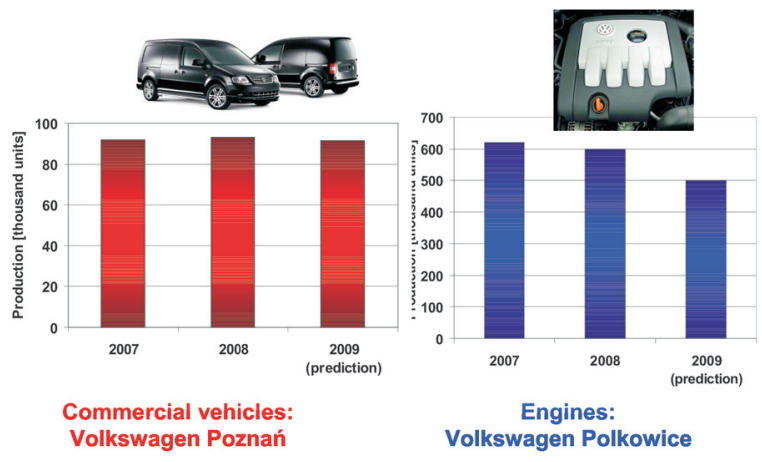

Fig. 14. The influence of the crisis on Volkswagen works in Poznan and Polkowice [6]

Rys. 14. Wpływ kryzysu na produkcję w zakładach firmy Volkswagen w Poznaniu i Polkowicach [6]

znaczna część klientów wybiera obecnie najtańsze modele samochodów wyposażone w silniki o zapłonie iskrowym. W zakładach Volkswagena w Poznaniu, gdzie produkowane są lekkie samochody dostawcze przewiduje się produkcję na poziomie zbliżonym do lat ubiegłych. Z przytoczonych danych można wnioskować, że kryzys w Polsce dotyczy raczej zakładów produkujących podzespoły pojazdów niż finalne pojazdy. 


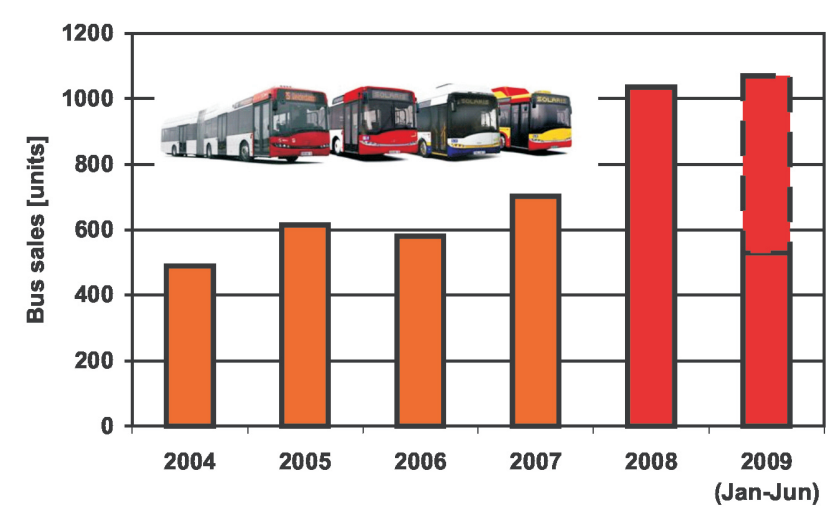

Fig. 15. SOLARIS Bus \& Coach Co. - bus sales results 2004-2009 [6] Rys. 15. Wyniki sprzedaży autobusów firmy SOLARIS Bus \& Coach w latach 2004-2009 [6]

\section{The influence of the crisis on the buyers' preferences}

The financial crisis has changed the buyers' priorities when purchasing new vehicles. The cost of the purchase and the costs of maintenance are much more important factors than a year ago. The purchasers preferences have shifted towards smaller and cheaper vehicles and those of high fuel economy. In the top ten of the most popular vehicles purchased in the EU this year only vehicles from segments A, B and C (Fig. 16) were on the list.

A trend of constantly increasing engine capacity and engine power output in European vehicles continuing for over 20 years has now been reversed (Fig. 17). An average engine capacity in the vehicles in 2009 has been reduced to the level of the beginning of the 1990s. Taking the engine technology advancement and downsizing the average engine power output has decreased less - to the level observed four years ago. The trend of constant growth in popularity of diesel engines has also been reversed (Fig. 17). The share of these engines in vehicles manufactured in the years 2006-2008 exceeded 50\% and in the first half of 2009 dropped to approximately $46 \%$. To some extent this could be credited to the success of some gasoline engine solutions such as direct injection, but still the main reason for the drop in the sales of diesel engines is the price of this engine type.

The changes in customer preferences will require from the manufacturers to focus more on the energy efficient vehicles. Even in the American market, a very conservative one in this respect, considerable changes are imminent. The Big Three from which the automotive crisis began have undertaken action to develop technologies reducing fuel consumption as well as electric vehicle technologies.

Ford has announced a plan of intense electrification of its fleet. In 2010 they are to launch a fully electric utility van. A year later a fully electric sedan is planned for launch
Jedynym segmentem rynku pojazdów w Europie, który nie zanotował w okresie kryzysu spadku sprzedaży jest segment autobusów. Zamówienia na autobusy składane są ze znacznym wyprzedzeniem, a ich zakup w znacznej części finansowany jest ze środków publicznych. Polska jest liczącym się w Europie producentem autobusów. W naszym kraju istnieje kilka fabryk autobusów należących do koncernów zagranicznych (tab. 1) oraz rodzimy producent - firma SOLARIS. Ta ostatnia przewiduje w 2009 r. dalszy wzrost sprzedaży w porównaniu do bardzo dobrego 2008 r. (rys. 15).

\section{Wpływ kryzysu na preferencje klientów i rozwój pojazdów}

Kryzys finansowy zmienił priorytety nabywców, którymi kierują się przy wyborze nowego samochodu. Znacznie większą rolę niż jeszcze rok temu odgrywa koszt zakupu i eksploatacji pojazdu. Preferencje klientów przesunęły się wyraźnie w kierunku pojazdów mniejszych i tańszych oraz oferujących małe zużycie paliwa. W pierwszej dziesiątce najchętniej kupowanych w Unii Europejskiej samochodów osobowych znalazły się w tym roku wyłącznie pojazdy z segmentów A, B i C (rys. 16).

Utrzymująca się od prawie 20 lat tendencja wzrostu objętości skokowej i mocy silnika w europejskich samochodach uległa obecnie odwróceniu (rys. 17). Średnia objętość skokowa silników montowanych w pojazdach zmniejszyła się w 2009 r. do poziomu z początku lat dziewięćdziesiątych ubiegłego wieku. Biorąc pod uwagę rozwój silników i tzw. downsizing, średnia moc silników spadła mniej, bo do poziomu sprzed czterech lat. Odwrócona została również tendencja stałego wzrostu popularności silników o zapłonie samoczynnym (rys. 17). W latach 2006-2008 udział tych silników w nowych samochodach osobowych przekraczał już 50\%, natomiast w pierwszej połowie 2009 r. spadł do około $46 \%$. W pewnym stopniu można to wiązać z rozwojem udanych konstrukcji silników o zapłonie iskrowym, wyposażonych w bezpośredni wtrysk paliwa, jednak jako 


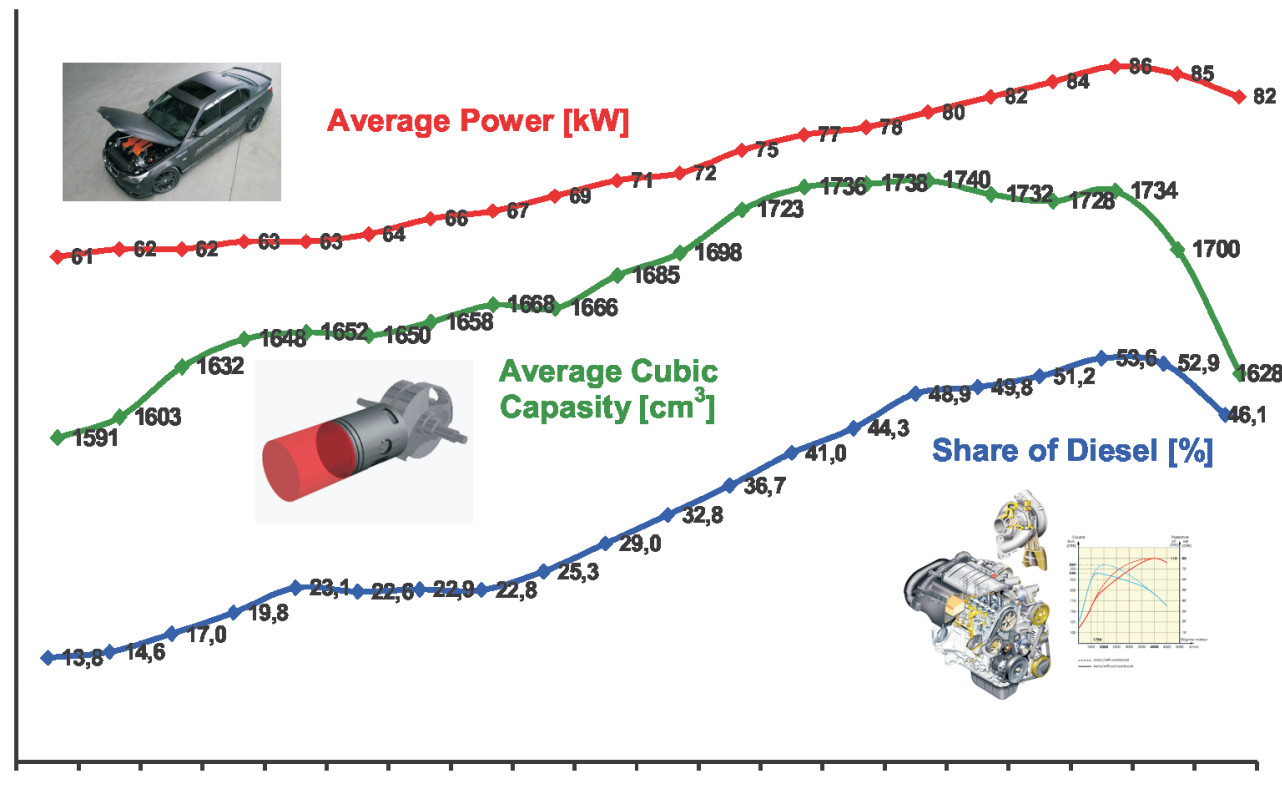

90

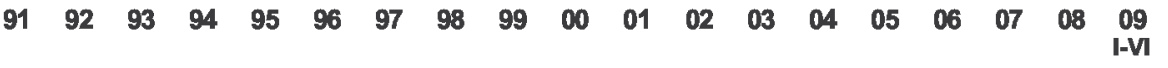

Fig. 17. Changes in customers' preferences over the last two decades [2]

Rys. 17. Zmiany preferencji nabywców nowych samochodów w ciagu ostatnich 20 lat [2] główny czynnik należy wskazać wyższą cenę pojazdu wyposażonego w silnik o zapłonie samoczynnym.

Zmiana preferencji klientów wymagać będzie od producentów położenia większego nacisku na rozwój pojazdów energooszczędnych. Nawet na konserwatywnym w tym względzie rynku amerykańskim przewidywane są istotne zmiany. „Wielka trójka”, od której rozpoczął się kryzys przemysłu motoryzacyjnego, podjęła intensywne działania na rzecz rozwoju technologii zmniejszających zużycie paliwa oraz pojazdów elektrycznych.

into the market. In general, by 2012 Ford plans to offer a family of vehicles: hybrid, plug-in hybrid and fully electric. The Ford's capital expenditure for the technologies reducing fuel consumption are estimated at USD14 billion within the next 7 years. The planned effect is a $36 \%$ reduction of fuel consumption in Ford vehicles in 2015.

General Motors presented a market version of Chevrolet Volt (Fig. 18) which is to be launched into the market in 2010. The car uses a plug-in hybrid technology under the market name of Voltec. This technology enables a 65 mile cruise using the electric motor exclusively. In this system the electric engine is more than twice more powerful $(111 \mathrm{~kW})$ than the combustion engine $(53 \mathrm{~kW})$. GM plans to apply Voltec in

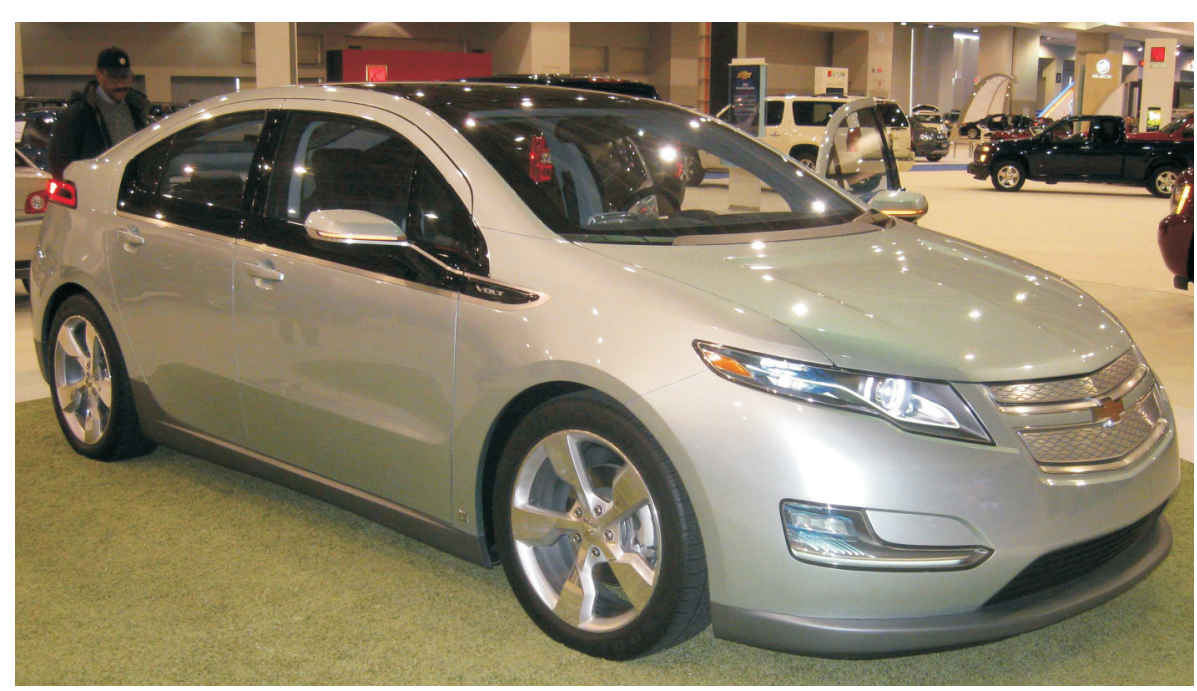

Fig. 18. Plug-in hybrid vehicle Chevrolet Volt presented at the 2009 Washington DC Auto Show Rys. 18. Samochód z hybrydowym układem napędowym typu plug-in hybrid Chevrolet Volt zaprezentowany na Wystawie Samochodowej w Waszyngtonie w 2009 r.
Ford ogłosił plan intensywnej ,elektryfikacji” floty produkowanych pojazdów. W roku 2010 na rynku ma pojawić się użytkowy van o napędzie czysto elektrycznym. Rok później planowane jest wprowadzenie na rynek elektrycznego sedana. Ogólnie do roku 2012 Ford zamierza zaoferować nabywcom rodzinę pojazdów o napędzie: hybrydowym, hybrydowym z możliwością ładowania akumulatorów z sieci elektrycznej (plug-in hybrid) oraz czysto elektrycznym. Nakłady Forda na technologie obniżające zużycie paliwa szacuje się na 14 miliardów dolarów w ciągu najbliższych 7 lat. Ich efektem ma być uzyskanie w 2015 r. zmniejszenia o $36 \%$ zużycia paliwa floty produkowanych przez Forda pojazdów.

General Motors przedstawił wersję produkcyjną samochodu Chevrolet Volt (rys. 18), który ma pojawić się $\mathrm{w}$ sprzedaży $\mathrm{w}$ 2010 r. W samochodzie tym zastosowano układ napędowy typu plug-in hybrid pod nazwą Voltec, który umożliwia przejechanie około $65 \mathrm{~km}$, korzystając tylko z silnika elektrycznego. W układzie tym silnik elektryczny ma ponad dwa razy większą moc $(111 \mathrm{~kW})$ niż silnik spalinowy $(53 \mathrm{~kW})$. GM planuje zastosowanie układu Voltec także w innych swoich pojazdach. W ciągu najbliższych 4 lat GM przewiduje inwestycje rzędu 2,9 miliarda dolarów w rozwój pojazdów o mniejszym 
other vehicles as well. Within the next 4 years GM forecasts to invest approximately USD 2.9 billion in the research and development seeking fuel reduction and alternative fuel solutions. The planned result is to launch 15 hybrid models by 2012 as well as making at least half of the manufactured fleet of vehicles compliant with the E85 technology.

Chrysler plans to introduce into the market a higher number of smaller vehicles of lower fuel consumption. In 2010 they plan to fit a hybrid drivetrain in Dodge Ram - their flagship pick-up truck and developing the first fully electric Chrysler vehicle. Similarly to GM Chrysler forecasts that by 2012 half of the manufactured vehicles will comply with the flex-fuel technology. All in all, the success of the Big Three and their plans will largely depend on their possibilities of securing necessary financing for the said investments. To date they have applied for financing of over USD 20 billion for the development of energy efficient vehicles

\section{Conclusions}

The automotive industry is one of the branches that suffered most as a result of the recession initiated by the financial crisis. We can suspect that the crisis in the automotive industry will generate long term adverse economic effects as this particular sector stimulates all the other branches of industry. These results may extend the recession itself and reduce the pace at which the world economies overcome the crisis. Currently, there is no uniform opinion among the experts as to the duration and intensity of the automotive crisis. The forecast presented by Business Monitor International - Automotives Insight indicates that the car sales in the coming years will grow but the scenario of this growth will depend on the result obtained in this year (Fig. 19).

For the last 10 years the sales in the EU remained on a constant level that amounted to 16.7-17.7 million vehicles. From the first half of 2008 the vehicle sales dropped rapidly zużyciu paliwa oraz zasilanych paliwami alternatywnymi. Efektem tego ma być zaoferowanie nabywcom do 2012 r. 15 modeli pojazdów hybrydowych oraz dostosowanie co najmniej połowy floty produkowanych pojazdów do zasilania paliwem E85.

Firma Chrysler zamierza wprowadzać na rynek większą liczbę mniejszych pojazdów o zmniejszonym zużyciu paliwa. W roku 2010 planowane jest zastosowanie napędu hybrydowego we flagowym pick-upie Dodge Ram oraz opracowanie pierwszego samochodu elektrycznego koncernu Chrysler. Podobnie jak GM, również Chrysler przewiduje, że do 2012 r. połowa produkowanych przez niego pojazdów będzie typu flex-fuel. Ostatecznie powodzenie ambitnych planów „wielkiej trójki” zależeć będzie w znacznej mierze od możliwości pozyskania niezbędnych środków finansowych na inwestycje. Do tej pory złożyli oni wnioski kredytowe na ponad 20 miliardów dolarów z przeznaczeniem na rozwój pojazdów o wysokiej sprawności energetycznej.

\section{Podsumowanie}

Przemysł motoryzacyjny jest jednym z sektorów gospodarki, które najbardziej ucierpiały w wyniku recesji zapoczątkowanej kryzysem finansowym. Można się spodziewać, że kryzys sektora motoryzacyjnego będzie generował odległe negatywne skutki gospodarcze, gdyż sektor ten stymuluje wiele innych, różnych gałęzi gospodarki. Skutki te mogą przyczynić się do przedłużenia okresu recesji i spowolnić tempo wychodzenia z kryzysu. Obecnie brak jest wśród ekspertów jednomyślności odnośnie do perspektywy czasowej i stopnia nasilenia kryzysu przemysłu motoryzacyjnego. Prognoza przedstawiona przez Business Monitor International - Automotives Insight wskazuje, że sprzedaż samochodów w następnych latach będzie wzrastać, jednak scenariusz tego wzrostu zależeć będzie od wyniku uzyskanego w bieżącym roku (rys. 19).

Przez ostatnie 10 lat sprzedaż w Unii Europejskiej utrzymywała się na podobnym poziomie, wynoszącym 16,7 do $17,7 \mathrm{mln}$ pojazdów. Od połowy 2008 r. sprzedaż pojazdów gwałtownie zmalała o prawie $3,5 \mathrm{mln}$ pojazdów poniżej poziomu ustalonego w minionych latach. Spadek sprzedaży na rynkach krajowych, wraz z załamaniem kluczowych rynków eksportowych, doprowadził do znacznego pogorszenia sytuacji ekonomicznej producentów. Przewidywany w 2009 r. 20-procentowy spadek sprzedaży samochodów w Unii Europejskiej oznaczać będzie zmniejszenie dochodów producentów o około 60 miliardów euro. 
by almost 3.5 million below the constant level set in the previous years. The drop in the sales in the domestic markets along with the collapse of the export markets have led to a bad financial situation of the manufacturers. The forecasted $20 \%$ drop in the sales of passenger vehicles for 2009 in the EU will translate into a drop in the manufacturers' revenues by approximately euro 60 billion.

The production of vehicles is characterized by a relatively low margin policy, high fixed costs and high capital expenditure on research and development related to the environment protection. Without access to financing during the crisis some of the manufacturers will face the threat of bankruptcy along with their suppliers and other related businesses. Hence, it is very important to initiate legislative actions that would stimulate the vehicle demand and production as well as facilitate financing.

As compared with other countries the financial crisis in Poland is rather mild. The difficulties mostly pertain to suppliers than the final product manufacturers. The shift in the market towards smaller, cheaper and more economical vehicles is advantageous from the point of view of the Polish vehicle manufacturing profile. That is why, Fiat Panda, manufactured in Tychy places 7 th in the list 9of the most frequently purchased vehicles in Europe.

The sales of new passenger vehicles in Poland from January to August 2009 amounted to 214626 units which is a growth by $1 \%$ as opposed to the same period in the previous year. This should be credited to a customers' positive vetting of their financial situation and optimistic data related to the condition of the Polish economy. In the second quarter of 2009 Poland was the only country in the EU that recorded an increase in the GDP (by 1.1\%). The economies of Greece and Cyprus, that also recorded an increase in the first quarter, in the second quarter did not sustain the results (drop in GDP by 0.2 and $0.7 \%$ ).

For the vehicle purchasers the crisis turned out very advantageous. A lower demand for vehicles generated better competition in the market and the necessity to come up with more attractive offers. Additional benefits for the purchasers are the subsidies for new vehicle purchase introduced in many countries. Another good result of the crisis is that the works on energy efficient vehicles (hybrid, electric, alternative fuel vehicles) have sped up.
Produkcja pojazdów charakteryzuje się względnie niskimi marżami, wysokimi kosztami stałymi oraz dużymi nakładami zawiązanymi z rozwojem nowych, przyjaznych środowisku technologii pojazdów. Bez dostępu do środków finansowych w okresie kryzysu niektórym producentom grozić będzie bankructwo, a upadek producentów stanowić będzie zagrożenie dla setek poddostawców i innych firm z nimi współpracujących. Stąd bardzo istotne są działania legislacyjne stymulujące popyt i produkcję pojazdów, a także ułatwienia kredytowe.

W porównaniu do innych krajów przebieg kryzysu przemysłu motoryzacyjnego w Polsce można uznać za łagodny. Trudności dotyczą w większym stopniu poddostawców, niż finalnych producentów pojazdów. Przesunięcie popytu rynku w kierunku samochodów mniejszych, tańszych i o mniejszym zużyciu paliwa jest korzystne z punktu widzenia polskiego profilu produkcji samochodów. Z tego względu produkowany w Tychach FIAT Panda zajmuje siódme miejsce wśród najchętniej kupowanych samochodów w Europie.

Sprzedaż nowych samochodów osobowych w Polsce w okresie od stycznia do sierpnia 2009 r. wyniosła 214 626 pojazdów, co oznacza wzrost o $1 \%$ w stosunku do analogicznego okresu ubiegłego roku. Należy wiązać to z pozytywną oceną przez potencjalnych klientów swojej sytuacji finansowej oraz optymistycznymi danymi na temat stanu polskiej gospodarki. W drugim kwartale 2009 r. Polska była jedynym krajem w Unii Europejskiej, który zanotował wzrost PKB (o 1,1\%). Gospodarki Grecji i Cypru, które obok Polski odnotowały wzrost PKB w pierwszym kwartale, w drugim radziły sobie już gorzej (spadek PKB odpowiednio o 0,2 i $0,7 \%$ ).

Dla nabywców samochodów kryzys okazał się korzystny. Mniejszy popyt na samochody wywołał wzrost konkurencji na rynku i konieczność wprowadzenia korzystniejszych ofert dla klientów. Dodatkowe korzyści dla nabywców zapewniają wprowadzone w wielu krajach programy dopłat przy zakupie nowego pojazdu. Innym korzystnym następstwem kryzysu jest przyspieszenie prac nad rozwojem energooszczędnych pojazdów, w szczególności hybrydowych i elektrycznych oraz pojazdów zasilanych paliwami alternatywnymi.

Paper reviewed

Prof. Jerzy Merkisz, DSc, DEng. - Professor in the Faculty of Working Machines and Transportation at Poznan University of Technology.

Prof. dr hab. inż. Jerzy Merkisz - Profesor na Wydziale Maszyn Roboczych i Transportu Politechniki Poznańskiej.

e-mail: jerzy.merkisz@put.poznan.pl
[1] Dane EUROSTAT - European Statistical Office: www.ec.europa.eu/eurostat.

[2] Dane European Automotive Manufacturers' Association: www.acea.be.

[3] Dane US Energy Information Administration: www.eia.doe.gov.

4] Dane Business Monitor International - Automotives Insight: www.autosinsight.com.

[5] Dane Głównego Urzędu Statystycznego: www.stat.gov.pl

[6] Informacja własna z firm: FIAT, Volkswagen, SOLARIS.

[7] Dane Instytutu Badań Rynku Motoryzacyjnego SAMAR: www.samar.pl. 